\title{
Questions of Scientific Research on Violence and Inequality Applied to Women
}

Mikhail F. Kostyuk ${ }^{1}$

Elena V. Kunts ${ }^{2}$

Journal for Educators, Teachers and Trainers, Vol. 12 (1)

https://jett.labosfor.com/

Date of reception: 10 October 2020

Date of revision: 07 January 2021

Date of acceptance: 06 April 2021

Mikhail F. Kostyuk, Elena V. Kunts (2021). Questions of Scientific Research on Violence and Inequality Applied to Women. Journal for Educators, Teachers and Trainers, Vol. 12(1). 143 - 146.

${ }^{1}$ Doctor of Law, professor, professor of the Department of State Law and Criminal Law Disciplines, Law Faculty of Federal State Budgetary Educational Institution of Higher Education Plekhanov Russian University of Economics, 36 Stremyanny per., Moscow 117997, Russian Federation,

${ }^{2}$ Doctor of Law, professor, Leading Researcher, Federal State Institution Research Institute of the Federal Penitentiary Service of Russia, 15a Narvskaya str., bldg.1, 125130 Moscow, Russian Federation 


\title{
Questions of Scientific Research on Violence and Inequality Applied to Women
}

\section{Mikhail F. Kostyuk ${ }^{1}$, Elena V. Kunts ${ }^{2}$}

${ }^{1}$ Doctor of Law, professor, professor of the Department of State Law and Criminal Law Disciplines, Law Faculty of Federal State Budgetary Educational Institution of Higher Education Plekhanov Russian University of Economics, 36 Stremyanny per., Moscow 117997, Russian Federation,

${ }^{2}$ Doctor of Law, professor, Leading Researcher, Federal State Institution Research Institute of the Federal Penitentiary Service of Russia, 15a Narvskaya str., bldg.1, 125130 Moscow, Russian Federation

Email ID: kost-mf@yanex.ru, 73kuntc@mail.ru

\begin{abstract}
In the last decade of the 21st century, research on discrimination and violence against women has increased rapidly. Such close attention of the world community to the inequality of women and violence against them contributes to a large-scale international recognition of the need and timely development of scientific approaches that take into account gender issues on a fairly stable basis. However, the problem of the legal status of women in connection with their increasing activity in public life has not received much attention from the point of view of scientific research. As a result, there are no comparative data in this area. Research work with a gender perspective is needed to assess the role and scope of this phenomenon and to draw scientific conclusions, regulations and recommendations for reforms in the adoption of draft laws, social policies and solutions.
\end{abstract}

Keywords: woman, discrimination, violence, inequality, gender, victimization, legal policy

\section{INTRODUCTION}

According to the Global Gender Gap Index ranking for 2019, Russia ranked 81st out of 159 countries, which was generated by four positions: 1) health care and probable life expectancy; 2) economy and career; 3) education; 4) political rights. It should be recognized that Russia in the ranking is bordered by Ethiopia and El Salvador, which gives grounds for a detailed study of the reasons for this situation. The Government of the Russian Federation has prepared a draft order under which it is planned to reduce the list of professions prohibited for women from 456 to 79 from January 1, 2021. At the same time, Russia will not ratify the 2011 The Council of Europe Convention on preventing and combating violence against women and domestic violence (Istanbul Convention), despite active discussion of the draft law on domestic violence. This position has two dimensions. The first is that with the adoption of such a law, society is seriously divided into two groups based on gender. Together with protection from family aggressors, there are many ways to use the law for blackmail, for taking away property and slander with the onset of severe social consequences for the victims, which, apparently to everyone, will be mainly men, which creates a ground for discrimination on the basis of gender.

The second dimension is that the law is written in line with the conceptual apparatus of the so-called Istanbul Convention, which Russia has not ratified and, as it turns out, pursuant to which this law is created. After the adoption of the law, the convention will have to be ratified, which means the automatic abolition of the law prohibiting homosexual propaganda and other sodomy.

Over the past five years, the political crisis between Russia, European countries and the United States has intensified, hindering understanding and cooperation between states. Many misunderstandings, disagreements and subsequent conflicts between states arise due to differences in culture, state structure, historical experience, traditions, religions, and most importantly - the inability to properly understand the official position of a single state, its true motives. It is important to note that men are not less discriminated against than women on the basis of gender in various branches of Russian law.

The scale and extent of violence against women can be determined in various ways. Official statistics have their negative aspects. Data on crimes recorded by the police only take into account cases that have come to the attention of police officers and that relate to offences. There are a number of reasons why crimes are not reported to the police and why police officers do not respond to them. Women victims of violence may feel shame and guilt and in many cases seek to hide the problem from the attention of neighbors, relatives and other acquaintances, especially if the offender is a close relative or acquaintance. Female victims are quite often threatened with physical harm if they turn to law enforcement for help. Police officers may assess the situation as a normal family 
quarrel that should not be registered as crimes. Therefore, violence against women is not covered by the law. The level of officially unreported crimes of violence against women is quite high.

\section{LITERATURE REVIEW}

In Russia, no study similar to the present has been found. Legal, including criminal law, issues of responding to big challenges are usually considered in relation to one of the research priorities. The problem of inequality, discrimination and violence is reflected in the works of such authors as S. G. Aivazova, U. M. Antonyan, Ya. I. Gilinsky, M. P. Kleimenov, I. S. Kon, I. Ya. Kazachenko, V.N. Kudryavtsev, E.V. Kunts, N.A. Lopashenko, L.N. Frolova, E.M. Chernyak, etc. So, the following works are of interest. V. Golubovskii, E. Kunts "Revisiting the Concept of Discrimination in Russian and Global Practice" (Opcion Ano 35, Especial No. 20 (2019)), V. Golubovskii, M. Kostyuk, E. Kunts "Features of Discrimination Based on Racial, National and Religious Grounds" (Opcion Ano 35, Especial No. 20 (2019)), which consistently address issues of discrimination and inequality, including by gender.

\section{MATERIALS AND METHODS}

The proposed study examines and analyzes not only the norms of criminal law and the norms of special acts in Russia and abroad, but also the main directions of scientific research on legal policy towards women, the potential consequences of the use of new developments and technologies and their possible impact on social relations in the future. The study uses the following methodological principles: the principle of objectivity, the principle of determinism, the principle of historicism, the principle of integrity, the principle of systemicity, the principle of structure, the principle of functionality, the principle of hierarchy, the principle of pluralism of explanation and understanding of social and legal phenomena and processes, the principle of comparison.

Delphi approach consists in collecting the opinions of specialists with deep knowledge or practical experience in related fields of knowledge. The legal statistics method is to obtain quantitative indicators on the state of crime in knowledge-intensive areas and branches of its study and comparison. The specified and sociological method consists in revealing of social reaction of a society to development of legal researches concerning women. A special place in the methodology of research is given to the method of legal simulation, as it will create a model of the impact of existing criminal legislation on the sphere of each of the challenges, as well as models of proposed legislative changes on the compliance with the priorities of society and state development. In addition to private and legal methods, it is envisaged to use the methodology of other social sciences.

\section{RESULTS}

The results of the analysis of physical and sexual violence against women suggest that the extent of victimization of women cannot be assessed either through surveys or through data reported to law enforcement agencies. The methods used to analyze victimization have not been able to provide information on specific data on violence against women. Domestic research on violence against women is not comparable due to differences in data collection methods and survey questions. In order to collect comparable data, it would be justified and timely to conduct a study on violence against women and discrimination as part of international cooperation. It should be noted that some countries have conducted national surveys on violence against women by interviewing a representative sample of women in the population, for example. These surveys focus on measuring physical and sexual violence, discrimination and inequality against women, for example, in Australia in 1996, Canada in 1993 and Finland in 1997.

While research on the extent of violence in different countries is important, there is a need for new methods of obtaining information on violations of laws against women and criminal justice systems, it is time to analyze the opinion of each individual woman. Systematic qualitative and quantitative research is needed to compare information from different sources and to compare information at the national, regional and international levels. There is a need for statistical data, including operational data, to assist in analyzing the nature of the crimes committed.

Determining the nature and extent of the gender balance in the criminal justice system will involve the preparation of multiple indicators and, above all, more complex methods for collecting and analyzing information on trafficking with women, which presents certain challenges.

Information on trafficking with women appears in the media, while scientific evidence on the subject is not always available.

\section{DISCUSSION}

Policies to prevent inequality, violence and discrimination against women should focus on improving their social and economic situation; social and community support is needed and, where possible, for most disadvantaged women in society. The implementation of international instruments that guarantee equality, justice and the protection of their rights must be at the center of responses taking into account possible criminal behavior by women. It is particularly important to analyze the role of women in criminal organizations in order to enhance 
information on such activities, the nature and extent of state participation, support and cooperation. It is justified to provide women with sustainable economic development opportunities to address women's victimization, especially through processes. Developing common strategies and strengthening communication networks between government agencies and non-governmental organizations is needed in order to provide better support to women who do not want to accept the role of victims. Guaranteed support for women and adolescent girls when they report being targeted and then testify in court is essential.

As well as removal of obstacles that prevent women from reporting crimes so that they can be supported through appropriate procedures, mechanisms and processes; and safeguarding the fundamental rights of women and girls who are victims of crime and providing them with the necessary support, protection and fair trial. Adequate measures by the state to adopt a number of provisions that are not limited to criminal sanctions, but also include compensation and civil duty, victim support measures, educational and information programs and awarenessraising campaigns involving the media, taking into account the challenges faced by women in judicial proceedings have to be developed. There is also a need for quality training for police officers, the criminal justice system, professionals and professionals working in the criminal justice system, with a focus on gender and human rights, to ensure that they understand the unacceptability of violence committed against women in all its forms, its impact and its consequences. Development of law enforcement standards in the practice and training of criminal justice officials to ensure that they uphold the principles of justice and equality in the eyes of the law and adequately respond to violence against women is needed together with improvement of the research on gender issues, with a focus on women's concerns, including those that may have an impact on legal policy relating to the status of women. Development of a gender-differentiated database and research on violence against women and assessment of good practices in preventing and combating such violence as well as planning for technical cooperation that is relevant or planned at the international or national level to make better use of existing resources is needed.

\section{CONCLUSION}

International cooperation in research provides information on inequality, discrimination, violence against women that is necessary for prevention and policy development. New research methods are also needed to connect practitioners, researchers and non-governmental and voluntary organizations in a wide range of fields. International collaboration makes it possible to compile comparative research results, which in turn makes it possible to develop benchmarks. With the help of research, it is possible to establish which methods are really useful, and with the help of cooperation it is possible to bring the results of research to an unlimited audience. New methods are needed to address the needs related to non-traditional types of crime faced by women both as offenders and as victims of these crimes. Research on this topic should be coordinated at the local, national and international levels.

\section{REFERENCES}

1. Ayvazova S.G. Патриархат// Словарь гендерных терминов Patriarkhat// Slovar' gendernykh terminov (Patriarchate// Dictionary of Gender Terms). M.: Regional'naya obshchestvennaya organizatsiya «Vostok-Zapad: Zhenskie Innovatsionnye Proekty»: Informatsiya XXI vek, 2002.

2. Galiakbarova N.R. Status i kar'era zhenshchiny v sovremennom rossiyskom obshchestve (Status and Career of a Woman in the Modern Russian Society): avtoref. dis. ... kand. sotsiol. Nauk (synopsis of a PhD. thesis in sociology). Penza, 2003.

3. Kunts E.V. Prestupnost' sredi zhenshchin i ee preduprezhdenie v sovremennoy Rossii (Crime among Women and its Prevention in Modern Russia). - Monografiya (Monograph). M., Yurlitinform, - 2009.

4. Kunts Elena, Golubovskii Vladimir, Legal Defense of Interethnic and Religious Relationships: Russian and International Experience. Journal of Advanced Research in Law and Economics. 2017. V.8, No 3 (25). P. 871-877.

5. Kunts, E. Features of Discrimination Based on Racial, National and Religious Groundsv/ M. Kostyuk, E. Kunts, V. Golubovskii/ / Opcion Ano 35, Especial No.20 (2019): 966-982

6. Kuntz, Y.V., and Golubovskiy, V.Y. 2015. The Legal Nature of Ethnic and Religious Conflicts. Indian 14. Journal of Science and Technology, 8(10), 1-7.

7. Frolova L.N. Status zhenshchiny v islame (The status of a Woman in Islam (in Russian) // Vestnik Adygeyskogo gosudarstvennogo universiteta. Seriya 1: Regionovedenie: filosofiya, istoriya, sotsiologiya, yurisprudentsiya, politologiya, kul'turologiya (Bulletin of Adygeya State University. Series 1: Regional Studies: Philosophy, History, Sociology, Law, Political Science, Cultural Studies). Maykop, Izd-vo Maykopskogo un-ta publ., 2009.

8. Chernyak E.M. Sotsiologiya sem'i (Sociology of a Family): M.: Izdatel'sko-torgovaya korporatsiya «Dashkov i K0» publ., 2004. 